\title{
Effect of Employee Biographical Characteristics and Perceived Organisational Support on Academic Staff Retention: A Case of Academic Staff in Universities in Kenya
}

\author{
Leonard N. Kiragu $^{1 *} \quad$ Dr. Dinah J. Kipkebut ${ }^{2} \quad$ Dr. Simon Kipchumba ${ }^{3}$ \\ 1.PhD student Department of Business Administration, Egerton University, Kenya \\ P. O. Box 13357 Nakuru, Kenya \\ 2.Senior Lecturer, Department of Business Administration, Egerton University, Kenya \\ P. O. Box 13357 Nakuru, Kenya \\ 3.Senior Lecturer, Department of Business Administration, Kabarak University, Kenya \\ P. O. Box private Bag Kabarak, Kenya
}

\begin{abstract}
The global problem of academic staff retention affects developed countries the same way as it affects developing countries. Perceived organizational support (POS) is a situation where employees develop an attitude or a belief about the degree to which their organization values their contributions and cares about their welfare. The objective of the present study is to examine the effects of perceived organisational support and employee biographical characteristics (age, gender, tenure in the university, tenure as an academic, job position and education) on academic staff retention in universities in Kenya. The sample of the study consisted of 388 academic staff drawn from a population of 13,441 academic staff in 31 public universities and 32 private universities in Kenya. Questionnaire method was used to collect data which was analyzed using inferential statistics which included Independent Samples $t$-Test, One Way Analysis of Variance (ANOVA), Pearsons Correlation analysis and Multiple Regression analysis. The analyses showed that the mean scores of Perceived Organisational Support (employees welfare) and POS (employees opinion and goals) did not differ significantly on the basis of gender, age, tenure in the university, tenure as an academic and university sector. In addition, the study found that the mean scores of POS (employees' opinions and goals) differed significantly on the basis of job position while mean scores of POS (employees' welfare) differed significantly on the basis of level of education. Further, the results showed that the mean scores of retention differed significantly on the basis of age, tenure in the university, tenure as an academic and job position. The results of correlation analysis showed that Perceived Organisational Support had a significant positive relationship with academic staff retention. Further, the results of multiple regression analysis showed that age and Perceived Organisational Support were significant positive predictors of retention. Finally, the results of multiple regression analysis showed that POS (employees welfare) influenced retention in public universities while POS (employees' opinions and goals) influenced retention in private universities. The study recommended that Universities should improve welfare matters such as pay, incentives, medical insurance among others and that Universities managers should be willing to listen to the employees concerns, soliciting their opinions and giving credit for implemented suggestions. The study further recommended that top university policy makers should implement various retention strategies targeting academics in the positions of senior lecturer and professors, and those with longer tenure in academics and in their universities.
\end{abstract}

Keywords: Biographical Characteristics, Perceived Organisational Support, Retention, Universities.

DOI: $10.7176 / \mathrm{EJBM} / 13-8-04$

Publication date: April $30^{\text {th }} 2021$

\subsection{Introduction}

Success of many organizations depends on employees with necessary skills in order to successfully perform duties required to attain the company's strategic goals (Robinson, 2004). Various scholars have identified employees as valuable assets in the achievement of organization goals (Armstrong, 2007; Schuler, 2011). Therefore, focusing on reducing employee turnover intentions can have positive impact on organizations resulting in increased employee productivity, performance, quality of work, profit and increased retention. The problem of academic staff retention is a worldwide issue that is experienced by most institutions of higher learning both in the developing and developed countries (Too, 2013). Institutions of higher learning are confronted with the tremendous challenge of identifying, recruiting and retaining high caliber staff, particularly lecturers (Bushe, Chiwira, and Chawawa, 2012). Various studies have found a positive relationship between perceived organisational support and employee retention (Khalid \& Nawab, 2018; Abdulrab, Zumrah \& Ameen, 2018; Cheng et al.,2020). Neves and Eisenberger (2014) refers to Perceived organizational support, as an understanding and attitude of a worker regarding the extent to which their contribution is valued and recognized by their institution and about their wellbeing. Research has revealed that POS has an effect on retention (Neves and Eiseneberger, 2014). Employees develop perceived organizational support in order to meet needs for approval, 
esteem and affiliation, and to assess the benefits of increased work effort. Eisenberger (2014) found that the behavioural outcomes of POS include increased retention and a decrease in withdrawal behaviours, such as absenteeism and turnover. Various studies have been conducted in Kenya to investigate the effects of perceived organisational support on the employee's retention (Chelangat, 2019; Miring'u, 2016; K'osuri, Eggesa \& Onyango, 2020). None of these studies have focused on the role of perceived organisational support in influencing academic staff retention which presents a knowledge gap on the need to investigate how perceived organizational support can influence retention of academic staff in universities. This study therefore sought to provide an empirical evidence of the effectiveness of perceived organizational support in retention of academic staff.

\subsection{Statement of the problem}

The worldwide problem of academic staff retention affects developed countries the same way as it affects developing countries in the world (Tettey, 2006). Previous studies on perceived organisational support found a negative relationship between perceived organisational support and employees' intention to quit (Dawley, Houghton \& Bucklew, 2010; Jayasundera \& Jayakody, 2017; Wong \& Wong, 2017; Alfisyahri, Etikariena \& Gatari, 2017). Other studies on perceived organisational support and retention reported a positive correlation between the two variables (Arasanmi \& Krishna, 2019; Pack, Jordan \& Turner, 2007; Abraham, Renaud \& Saulquin, 2016; Satardien, 2014). All these studies suggest that perceived organisational support can contribute to employee retention. Studies, for instance, Arasanmi \& Krishna (2019) linked perceived organizational support to employee retention but the focus was in New Zealand thus indicating a contextual gap. Khalid, \& Nawab, (2018) examined the effects of perceived organizational support on employee retention. The study found a positive significant relationship between perceived organizational support and employee retention but presented a contextual gap since it focused on Pakistan. In Kenya, Miring'u (2016) carried a study on perceived organizational support and organizational commitment in the dairy industry in Kenya. The study however focused on organizational commitment as the dependent variable thus creating conceptual gap on the need to test the effects of perceived organizational support on another dependent variable. Some of the above-mentioned studies were done in developed economies while some local studies were done in a non-academic environment and the contextual differences may yield different results, therefore findings and conclusions of these studies may not apply to universities operating in the Kenyan context. The review unveils contextual, methodological and empirical gaps worth addressing. This study therefore is aimed at filling up the identified gaps in previous studies and will attempt to answer the research question; does perceived organizational support influence the academic staff retention in universities in Kenya?

\subsection{Literature review}

The literature review will discuss various aspects of the study variables namely, perceived organizational support, biographical characteristics and employee retention.

\subsection{Perceived Organisational Support}

Perceived Organizational Support is viewed as the assurance that assistance will be readily available from the organization when help is needed to carry out one's job effectively or to deal with stressful situations (Rhoades \& Eisenberger, 2002). Dabos and Rousseau (2004) found that when an organization provides employees with fair treatment and when they value their employees' contributions and well-being, the employees will feel obligated to reciprocate. The employee's reciprocal act can include higher organizational commitment and loyalty which results in a decreased intention to quit the organization (Allen, Lynn and Rodger, 2003). The perceived organizational support (POS) experience, which refers to the degree to which the company recognizes the efforts of its employees and cares for their well-being, has been used to describe the social relationship between the employer and the employee (Allen et al., 2003). Previous studies have shown that POS increases employee engagement and their sense of duty to the company (Hashmi \& Jabeen, 2019; Shields, 2017; Nikhil \& Arthi, 2018). Thus, through their loyalty and duty to an organization, POS will improve the retention behavior of employees (Shah \& Asad, 2018). In spite of the longevity of service within an organisation, it has been said that in order to perform up to and above anticipated standards, it is vital for workers to have the required support from their organization. Eisenberger, Malone \& Presson (2016) clarified that by taking care of the organization's wellbeing, POS makes workers feel obligated to help the organization accomplish its goals. Aydin \& Tuzun (2019) highlighted the fact that the ability of workers to retain membership in an organization would also increase as effort-outcome expectations increase due to POS. Individuals with high POS will also be less inclined to explore alternative possibilities (Nurjaman, Marta \& Eliyana, 2019). Eisenberger (2016) views perceived organizational support as consisting employees' welfare and employee's opinions and goals. Employee welfare is an "umbrella concept" including various services, benefits, and facilities offered to employees with the aim of fostering their working conditions and professional growth. Assessments of welfare measures are both objective and subjective. The former includes interventions regarding allowances, housing, transportation, medical insurance, wellness 
coverage, and so on (Schmitz and Schrader, 2015). The latter includes less tangible benefits such as perceived working conditions, the interpersonal environment in which work takes place, and organizational actions and support perceived by employees (Zhong et al., 2016). Employees opinions and goals develop when an employee feels that the supervisor is willing to listen to the employees concerns, soliciting their opinions and giving credit for implemented suggestions from employees (Colakoglu, 2018).

\subsection{Biographical characteristics}

Literature has disclosed that age, gender, tenure, education and position are biographical variables that have been found to have a steady relationship with retention and turnover intentions (Plooy \& Roodt, 2012). Biographical variables have been selected because they impact employee retention strategies. Various studies in which biographical factors have been employed to investigate turnover intentions have shown that they are strong predictors of employee's retention (Agyeman \& Ponniah, 2014; Hayes, 2015; Sule \& Omoankhalen, 2019).

Age

Various studies have found significant relationship between age and employee retention (Govindaraju, 2018; Healy, Lehman Mcdaniel, 2016; Gupta, Kumar \& Seemarani, 2015). Monks (2012) found that older employees were more likely to stay employed with their organization than younger employees. Lambert et al. (2012) found that turnover intentions decreased among older employees and those with longer tenure in the organization. Similarly, Okun et al. (2013) reported that younger employees (35 years and under) were more likely to move to new jobs than employees aged 35 to 55 years. In addition, Gibson \& Sodeman (2014) reported that employees between aged between 35 and 55 years were relatively stable, focused, and loyal to their organizations unlike employees aged below 35 years who were more likely to turnover. Murupus \& Kipkebut (2015) found that older employees were less likely to turnover than younger employees.

Gender

Research studies have found conflicting results in the relationships between gender and retention. Some studies have found insignificant relationship between gender and turnover intention (Hayes, 2015; Obwoyere \& Kipkebut, 2016; Kamau, 2018). Other studies have found that female employees were more likely to quit their jobs unlike male employees who were more likely to stay (Choong, Keh, Tan \& Tan, 2013; Huang \& Gamble, 2015). On the other hand, some studies have found that male employees have higher levels of turnover intentions than female employees (Lyness \& Judiesch, 2001; Jadoo et al., 2015).

\section{Job Tenure}

Studies have found that employees with long work experience have a low turnover tendency unlike employees with short tenure (Couch, 2011; Almalki, FitzGerald \& Clark, 2012; Lambert et. al., 2012; Murupus \& Kipkebut, 2015). Research shows that length of service is positively related to organizational commitment and in turn, retention. When an individual's length of service with a particular organization increases, he or she may build up an emotional attachment with the organization which makes it difficult to switchover (Giao, 2020). Ng \& Sorensen (2008) found that retention was high among employees with long tenure due to familiarity with their work. Samad (2016) found a negative and significant relationship between tenure and turnover intentions while on the other hand, Mensah, Augustine \& Oteng (2017) found no significant relationship between number of years worked and turnover intentions.

\section{Level of Education}

Studies have found that level of education was positively related to turnover intentions and negatively related to retention (Kipkebut, 2013; Murupus \& Kipkebut, 2015; Choong et al., 2013). Several studies have reported that employees with advanced educational levels experience more intention to leave while those with low education levels are more likely to stay (Mulwa, 2010; Al Mamun \& Hasan, 2017; Wangare, 2017). Highly educated employees have been found to be dissatisfied with their jobs due to unfulfilled high expectations and thus were more likely to turnover unlike employees with low levels of education. Other studies have found insignificant relationships between education and turnover intentions or retention (Choong et al., 2013; Du Plooy \& Roodt, 2013).

\section{Job Position}

Job position has been found to have significant effect on retention. Kónya, Matić \& Pavlović, (2016) reported that retention was higher among employees performing managerial jobs than those performing non-managerial jobs. According to Kónya et al. (2016) managerial employees enjoy better benefits compared to non-managerial employees leading to commitment to stay in the organisation. Some studies have found that employees who perform unchallenging, low skill jobs were more likely to stay unlike employees with high status jobs who have better job opportunities. Some studies have found insignificant relationships between job position and turnover intentions (Obwoyere \& Kipkebut, 2016; Murupus \& Kipkebut, 2015; Du Plooy \& Roodt (2013).

\subsection{Academic Staff Retention}

Retention relates to the degree to which an employer retains its employees and may be measured as the ratio of 
employees with a specified length of service (typically one year or more) expressed as a percentage of overall workforce numbers (Chaminade, 2007). Employee retention is a voluntary move by an organisation to create an environment which engages employees for the long term (Chaminade, 2007). In a business setting, the goal of employers is usually to decrease employee turnover, thereby decreasing training costs, recruitment costs and loss of talent and organizational knowledge (Allen, Bryant and Vardaman, 2010). University Academic staff attrition represents the loss of experienced staff from the system especially where those who are leaving the profession are more effective or more qualified academic. This may have the effect of leaving a less capable pool of staff in the lecture room as well as lead to demoralization among remaining employees (Selesho, 2014). Reduction of academic staff attrition is a pertinent issue in public and private Universities in Kenya yet these institutions are operating in a highly competitive environment and hence depend on these staff for success and sustainability (Mukwahana et al, 2016). The teaching career nationwide is continuously beset by several problems. One of the most severe problems in the teaching profession is the high turnover incidences of its essential human resource: the lecturers. Indeed, governments in both developing and developed countries are finding it difficult to retain lecturers in Universities (Waswa, 2008). Several studies have been conducted globally and all point to a problem of retention (Manogharan, 2018; Njanjobea, 2016; Mubarak, Wahab \& Khan, 2012; Mbirithi, 2013; Iddrisu, Alhassan \& Kinder, 2014).

\subsection{Research Hypotheses}

From the above reviewed literature, the following research hypotheses are proposed:

$\mathrm{H}_{01}$ : There are no differences in Perceived Organisational Support and academic staff retention based on employee biographical characteristics, namely: age, gender, university and job tenure, education and job position.

$\mathrm{H}_{02}$ : There are no significant relationships between Perceived Organisational Support and retention among academic staff in Universities in Kenya

$\mathrm{H}_{0} 3$ : The combined effect of employee biographical characteristics and Perceived Organisational Support do not have a significant effect on retention among academic staff in Universities in Kenya.

\subsection{Methodology}

The study adopted a cross-sectional survey research design. Using Nassiuma's (2000) formula a sample of 13 universities from a total of 63 universities in Kenya was derived. The population of the study was 13,441 academic staff from the 63 universities in Kenya. A formula by Yamane (1967) was used to derive a sample size of 388 academic staff. Stratified random sampling was used to determine the sample size per university and thereafter simple random sampling was used to select the respondents from each of the selected universities. Questionnaires were distributed through "drop and pick" method. A total of 302 questionnaires were filled giving a response rate of $77.8 \%$ which is excellent. Mugenda \& Mugenda (2012) asserts that a response rate of 50\% is adequate for analysis and reporting; a rate of $60 \%$ is good while a response rate of $70 \%$ and above is excellent.

Table 1: Summary of biographical characteristics of the respondents

\begin{tabular}{|l|l|l|}
\hline & Frequency & Percent (\%) \\
\hline Gender & & \\
Female & 194 & 64.2 \\
\hline & 108 & 35.8 \\
\hline Age & 302 & 100 \\
Below 30 years & & \\
$30-39$ years & 13 & 4.3 \\
$40-49$ years & 91 & 30.1 \\
50 - 59 years & 122 & 40.4 \\
60 years and above & 54 & 17.9 \\
\hline & 22 & 7.3 \\
\hline Level of Education & 302 & 100 \\
Bachelors Degree & & \\
Masters Degree & 12 & 4.0 \\
Doctorate Degree & 134 & 44.4 \\
\hline & 156 & 51.7 \\
\hline Tenure as an academic & 302 & 100 \\
5 years and below & & \\
6-10 years & 49 & 16.2 \\
$11-15$ years & 108 & 35.8 \\
16 years and above & 67 & 22.2 \\
\hline
\end{tabular}




\begin{tabular}{|l|l|l|}
\hline & Frequency & Percent (\%) \\
\hline & 302 & 100 \\
\hline Tenure in the present university & & \\
Below 10 years & 181 & 59.9 \\
10 - 19 years & 74 & 24.5 \\
20 years and above & 47 & 15.6 \\
\hline & 302 & 100 \\
\hline Position & & \\
Assistant Lecturer & 88 & 29.1 \\
Lecturer & 123 & 40.7 \\
Senior Lecturer & 55 & 18.2 \\
Professor & 36 & 11.9 \\
\hline & 302 & 100 \\
\hline
\end{tabular}

\subsection{Measurement of variables}

Following extensive review of the literature, the questionnaire to collect data for the study was developed and measured on a 5-point likert scale ranging from strongly agree to strongly disagree, where 1 indicates Strongly Disagree, 2-Disagree, 3-Uncertain, 4-Agree and 5-Strongly Agree. The reliability of the study instrument was tested using Cronbach Alpha test and the results showed acceptable reliability coefficients as follows: Perceived Organisational Support $(\alpha=0.816)$ and academic staff retention $(\alpha=0.629)$. The employee biographical characteristics are as follows: age, gender, tenure as an academic, tenure in the current university, education and job position.

\subsection{RESULTS}

The testing of the study hypotheses was subjected to statistical analysis as shown below. Independent samples ttest and One-way Analysis of Variance (ANOVA) was used to test Hypothesis One, Pearson Correlation analysis was carried out to test Hypothesis Two while multiple regression analysis was conducted to test Hypothesis Three and Four.

i. Results of Independent samples t-tests and one-way Analysis of Variance (ANOVA)

$H_{01}$ : There are no significant differences in perceived organisational support and academic staff retention based on employee biographical characteristics, namely: age, gender, university and job tenure, education and job position.

a) Gender

Table 2: Results of Independent Samples t-test exploring differences in Perceived Organisational Support and academic staff retention based on gender

\begin{tabular}{lllrrrrr}
\hline Variables & & Gender & $\mathrm{N}$ & Mean & $\begin{array}{c}\text { Std. } \\
\text { Deviation }\end{array}$ & t & Sig. \\
\hline Perceived Organisational & Support & Male & 194 & 9.41 & 3.18 & .295 & .768 \\
(Employees Welfare) & & Female & 108 & 9.30 & 3.04 & & \\
Perceived Organisational & Support & Male & 194 & 9.83 & 3.51 & 1.115 & .266 \\
(Employees Opinions and Goals) & Female & 108 & 9.40 & 2.64 & & \\
Academic Staff Retention & Male & 194 & 25.68 & 5.49 & -.184 & .854 \\
& & Female & 107 & 25.80 & 5.66 & & \\
\hline
\end{tabular}

The results in Table 2 show that there were no statistically significant differences in the mean scores of perceived organisational support and academic staff retention among male and female respondents $(p>0.05)$. This suggests that gender of academic staff did not influence satisfaction with perceived organizational support and decision to remain or leave the university. 
b) Age

Table 3: Results of One-Way ANOVA exploring differences in perceived organisational support and academic staff retention based on age

\begin{tabular}{|c|c|c|c|c|c|c|}
\hline & Age of respondents & $\mathrm{N}$ & Mean & $\begin{array}{c}\text { Std. } \\
\text { Deviation }\end{array}$ & $\mathrm{F}$ & Sig. \\
\hline \multirow{4}{*}{$\begin{array}{l}\text { Perceived Organisational } \\
\text { (Employees Welfare) }\end{array}$} & Below 30 years & 13 & 10.62 & 2.40 & \multirow[t]{4}{*}{2.139} & \multirow[t]{4}{*}{.095} \\
\hline & 30 to 39 years & 91 & 8.97 & 3.22 & & \\
\hline & 40 to 49 years & 122 & 9.19 & 3.14 & & \\
\hline & 50 years and above & 76 & 9.92 & 3.02 & & \\
\hline \multirow{4}{*}{$\begin{array}{l}\text { Perceived Organisational Support } \\
\text { (Employees Opinions and Goals) }\end{array}$} & Below 30 years & 13 & 10.31 & 1.93 & \multirow[t]{4}{*}{.890} & \multirow[t]{4}{*}{.447} \\
\hline & 30 to 39 years & 91 & 9.25 & 3.14 & & \\
\hline & 40 to 49 years & 122 & 9.75 & 3.71 & & \\
\hline & 50 years and above & 76 & 9.95 & 2.61 & & \\
\hline \multirow[t]{4}{*}{ Academic Staff Retention } & Below 30 years & 12 & 30.17 & 4.04 & \multirow[t]{4}{*}{5.036} & \multirow[t]{4}{*}{.002} \\
\hline & 30 to 39 years & 91 & 26.49 & 5.01 & & \\
\hline & 40 to 49 years & 122 & 25.60 & 5.60 & & \\
\hline & 50 years and above & 76 & 24.30 & 5.81 & & \\
\hline
\end{tabular}

The results in Table 2 show that there were no statistically significant differences in the mean scores of POS (employees' welfare) and POS (employees opinions and goals) among academic staff in different age groups ( $p>$ 0.05). This means that age did not influence satisfaction or dissatisfaction with perceived organisational support. On the other hand, the analysis showed that there were significant differences in the mean scores of academic staff retention based on different age groups of respondents $(\mathrm{F}=5.036, \mathrm{p}=.002)$. Post-hoc comparisons using Tukey HSD analysis showed that respondents aged below 30 years had significantly higher mean scores $(M=30.17)$ than respondents aged $30-39$ years $(M=26.49), 40-49$ years $(M=25.60)$ and 50 years and above $(M=24.30)$. This suggests that respondents aged below 30 years were more likely to continue working in their universities unlike respondents aged 30 years and above.

c) Tenure in the university

Table 4: Results of One-Way ANOVA exploring differences in Perceived Organisational Support and academic staff retention based on tenure in the university

\begin{tabular}{lclrrrrr}
\hline & & Years worked in the & $\mathrm{N}$ & Mean & $\begin{array}{c}\text { Std. } \\
\text { Deviation }\end{array}$ & F & Sig. \\
\hline Perceived & Organisational & Below 10 years & 181 & 9.40 & 3.07 & .497 & .609 \\
Support & (Employees & 10-19 years & 74 & 9.09 & 3.36 & & \\
Welfare) & & 20 years and above & 47 & 9.66 & 2.99 & \\
Perceived & Organisational & Below 10 years & 181 & 9.66 & 2.74 & .173 & .842 \\
Support & (Employees & 10-19 years & 74 & 9.57 & 4.49 & & \\
Opinions and Goals) & 20 years and above & 47 & 9.91 & 2.57 & & \\
Academic Staff Retention & Below 10 years & 180 & 26.37 & 5.32 & 5.194 & .006 \\
& & 10-19 years & 74 & 25.58 & 5.61 & & \\
\hline
\end{tabular}

The results in Table 3 show that there were no statistically significant differences in the mean scores of POS namely, employees' welfare and employee's opinions and goals among academic staff based on tenure in the university $(\mathrm{p}>0.05)$. This means that years worked in the current university did not influence satisfaction or dissatisfaction with perceived organisational support. On the other hand, the analysis showed that there were significant differences in the mean scores of academic staff retention based on tenure in the university $(\mathrm{F}=5.194$, $\mathrm{p}=0.006$ ). Post-hoc comparisons using Tukey HSD showed that respondents who had worked in the current university for below 10 years $(M=26.37)$ had significantly higher mean scores than respondents who had worked in the current university for 20 years and above $(\mathrm{M}=23.49)$. There were no significant differences in retention among academics who had worked in their universities for between 10 to 19 years. This suggests that respondents who had worked in their current universities for 20 years and above were more likely to quit their jobs unlike respondents who had worked in their current universities for less than 10 years. 
d) Tenure as an academic

Table 4: Results

of One-Way ANOVA exploring differences in Perceived Organisational Support and academic staff retention based on tenure as an academic

\begin{tabular}{|c|c|c|c|c|c|c|c|}
\hline & & $\begin{array}{l}\text { Years worked as an } \\
\text { academic }\end{array}$ & $\mathrm{N}$ & Mean & $\begin{array}{c}\text { Std. } \\
\text { Deviation }\end{array}$ & $\mathrm{F}$ & Sig. \\
\hline \multirow{4}{*}{$\begin{array}{l}\text { Perceived Organisational } \\
\text { (Employees Welfare) }\end{array}$} & \multirow[t]{4}{*}{ Support } & 5 Years and Below & 49 & 8.86 & 3.21 & \multirow[t]{4}{*}{1.227} & \multirow[t]{4}{*}{.300} \\
\hline & & $6-10$ years & 108 & 9.22 & 3.01 & & \\
\hline & & $11-15$ years & 67 & 9.37 & 3.26 & & \\
\hline & & 16 years and above & 78 & 9.88 & 3.10 & & \\
\hline Organisational & Support & 5 Years and Below & 49 & 9.37 & 3.00 & \multirow[t]{4}{*}{1.450} & \multirow[t]{4}{*}{.228} \\
\hline \multirow[t]{3}{*}{ (Employees Opinions and Goals) } & & $6-10$ years & 108 & 9.28 & 2.72 & & \\
\hline & & $11-15$ years & 67 & 10.10 & 4.58 & & \\
\hline & & 16 years and above & 78 & 10.05 & 2.49 & & \\
\hline \multirow{4}{*}{\multicolumn{2}{|c|}{ Academic Staff Retention }} & 5 Years and Below & 48 & 26.15 & 6.40 & \multirow[t]{4}{*}{2.833} & \multirow[t]{4}{*}{.039} \\
\hline & & $6-10$ years & 108 & 26.28 & 5.13 & & \\
\hline & & $11-15$ years & 67 & 26.34 & 5.56 & & \\
\hline & & 16 years and above & 78 & 24.17 & 5.32 & & \\
\hline
\end{tabular}

The results in Table 4 show that there were no statistically significant differences in the mean scores of perceived organisational support namely, employees' welfare and employee's opinions and goals among academic staff based on tenure as an academic $(\mathrm{p}>0.05)$. This means that years worked as an academic did not influence satisfaction or dissatisfaction with perceived organisational support. On the other hand, the analysis showed that there were significant differences in the mean scores of academic staff retention based on tenure as an academic $(\mathrm{F}=2.833, \mathrm{p}=0.039)$. Post-hoc comparisons using Tukey HSD showed that respondents who had worked as academics for $6-10$ years $(M=26.28)$ and $11-15$ years $(M=26.34)$ had significantly higher mean scores than respondents who had worked as academics for 16 years and above $(\mathrm{M}=24.17)$. This suggests that respondents who had worked as academics for 16 years and above were more likely to quit their jobs unlike respondents who had worked as academics between 6 to 15 years.

Position

Table 5: Results of One-Way ANOVA exploring differences in perceived organisational support and academic staff retention based on job position

\begin{tabular}{|c|c|c|c|c|c|c|c|}
\hline & & Position & $\mathrm{N}$ & Mean & $\begin{array}{c}\text { Std. } \\
\text { Deviation } \\
\end{array}$ & $\mathrm{F}$ & Sig. \\
\hline \multirow{4}{*}{$\begin{array}{l}\text { Perceived Organisational } \\
\text { (Employees Welfare) }\end{array}$} & \multirow[t]{4}{*}{ Support } & Assistant Lecturer & 88 & 8.93 & 2.99 & \multirow[t]{4}{*}{1.244} & \multirow[t]{4}{*}{.294} \\
\hline & & Lecturer & 123 & 9.57 & 3.21 & & \\
\hline & & Senior Lecturer & 55 & 9.82 & 3.34 & & \\
\hline & & Professor & 36 & 9.06 & 2.76 & & \\
\hline Organisational & Support & Assistant Lecturer & 88 & 8.82 & 2.73 & \multirow[t]{4}{*}{3.471} & \multirow[t]{4}{*}{.017} \\
\hline \multirow{3}{*}{\multicolumn{2}{|c|}{ (Employees Opinions and Goals) }} & Lecturer & 123 & 10.25 & 3.82 & & \\
\hline & & Senior Lecturer & 55 & 9.71 & 2.51 & & \\
\hline & & Professor & 36 & 9.75 & 2.71 & & \\
\hline \multirow{4}{*}{\multicolumn{2}{|c|}{ Academic Staff Retention }} & Assistant Lecturer & 87 & 26.32 & 5.50 & \multirow[t]{4}{*}{2.628} & \multirow[t]{4}{*}{.050} \\
\hline & & Lecturer & 123 & 26.28 & 5.28 & & \\
\hline & & Senior Lecturer & 55 & 24.64 & 5.98 & & \\
\hline & & Professor & 36 & 24.03 & 5.48 & & \\
\hline
\end{tabular}

The results in Table 5 show that there were no statistically significant differences in the mean score of perceived organisational support (employees' welfare) among academic staff based on job position $(\mathrm{p}>0.05)$. This means that position held did not influence satisfaction or dissatisfaction with POS (Employees Welfare). On the other hand, the analysis showed that there were significant differences in the mean scores of POS (Employees Opinions and Goals) based on position held $(\mathrm{F}=3.471, \mathrm{p}=.017)$ with Lecturers $(\mathrm{M}=10.25)$ having significantly higher mean scores than Assistant Lecturers $(\mathrm{M}=8.82)$. This suggests that Lecturers were more likely to be satisfied with POS (employees opinions and goals) in the universities than Assistant Lecturers. Further, results showed that Assistant Lecturers $(M=26.32)$ had significantly higher mean scores than Professors $(M=24.03)$. This suggests that Assistant Lecturers were more likely to stay in their universities than Professors. 


\section{Level of Education}

Table 6: Results of One-Way ANOVA exploring differences in Perceived Organisational Support and academic staff retention based on level of education

\begin{tabular}{|c|c|c|c|c|c|c|}
\hline & Level of Education & $\mathrm{N}$ & Mean & $\begin{array}{c}\text { Std. } \\
\text { Deviation }\end{array}$ & $\mathrm{F}$ & Sig. \\
\hline Organisational & Bachelor's Degree & 12 & 7.33 & 2.67 & 3.152 & .044 \\
\hline \multirow[t]{2}{*}{ Support (Employees Welfare) } & Masters Degree & 134 & 9.26 & 3.08 & & \\
\hline & Doctorate Degree & 156 & 9.62 & 3.15 & & \\
\hline Organisational & Bachelor's Degree & 12 & 8.42 & 2.75 & 1.800 & .167 \\
\hline \multirow{2}{*}{$\begin{array}{l}\text { Support (Employees Opinions } \\
\text { and Goals) }\end{array}$} & Masters Degree & 134 & 9.46 & 2.78 & & \\
\hline & Doctorate Degree & 156 & 9.96 & 3.58 & & \\
\hline \multirow[t]{3}{*}{ Academic Staff Retention } & Bachelor's Degree & 12 & 27.50 & 4.78 & 1.475 & .231 \\
\hline & Masters Degree & 133 & 26.11 & 5.37 & & \\
\hline & Doctorate Degree & 156 & 25.26 & 5.72 & & \\
\hline
\end{tabular}

The results of one-way ANOVA in Table 6 shows that there were no statistically significant differences in the mean scores of POS (employees' Opinions and Goals) and academic staff retention among academic staff based on the level of education $(\mathrm{p}>0.05)$. On the other hand, the analysis showed that the mean scores of POS (Employees welfare) differed significantly on the basis of level of education $(F=3.152, p=.044)$. Post-hoc comparisons using Tukey HSD showed that respondents with Bachelors degree had significantly lower mean scores $(M=7.33)$ than respondents with Masters $(M=9.36)$ and Doctorate $(M=9.62)$. This shows that academic staff with Bachelors degree, who are usually Graduate Assistants, are dissatisfied with level of support from their universities on welfare issues as compared to academics with Masters and Doctorate degrees.

University Sector

Table 7: Results of One-Way ANOVA exploring differences in Perceived Organisational Support and academic staff retention based on university sector.

\begin{tabular}{lllrrrr}
\hline University Sector & & N & Mean & Std. Deviation & t & Sig. \\
\hline Perceived Organisational Support & Public University & 176 & 9.32 & 3.06 & -.287 & .775 \\
(Employees Welfare) & Private University & 126 & 9.43 & 3.23 & & \\
Perceived Organisational Support & Public University & 176 & 9.57 & 3.49 & -.646 & .519 \\
(Employees Opinions and Goals) & Private University & 126 & 9.82 & 2.83 & & \\
Academic Staff Retention & Public University & 175 & 25.50 & 5.66 & -.837 & .403 \\
& Private University & 126 & 26.04 & 5.38 & & \\
\hline
\end{tabular}

The results of one-way ANOVA in Table 7 shows that there were no statistically significant differences in the mean scores of perceived organisational support namely, POS (employees' welfare), POS (employee's opinions and goals) and academic staff retention based on the university sector ( $p>0.05)$. This means that the university sector did not influence satisfaction or dissatisfaction with perceived organisational support and retention.

ii. Results of Pearson Correlation analysis

Hypotheses Two sought to determine the effect of perceived organisational support on academic staff retention. The hypotheses were tested using Pearson's Correlation analysis which determines the strength and direction of the relationships among the study variables.

Ho2: $_{\text {: }}$ There are no significant relationships between Perceived Organisational Support and retention among academic staff in Universities in Kenya

Table 8: Pearson's Correlation Analysis exploring the relationship between perceived organisational support and academic staff retention

\begin{tabular}{|c|c|c|c|c|}
\hline & & $\begin{array}{c}\text { POS } \\
\text { (Employees } \\
\text { Welfare) }\end{array}$ & $\begin{array}{c}\text { POS (Employees } \\
\text { Opinions and Goals) }\end{array}$ & $\begin{array}{l}\text { Academic Staff } \\
\text { Retention }\end{array}$ \\
\hline (Employees & Pearson Correlation & 1 & $.637^{* *}$ & $.239^{* *}$ \\
\hline Welfare) & Sig. (2-tailed) & & .000 & .000 \\
\hline & $\mathrm{N}$ & 302 & 302 & 301 \\
\hline (Employees & Pearson Correlation & $.637^{* *}$ & 1 & $.244^{* *}$ \\
\hline Opinions and & Sig. (2-tailed) & .000 & & .000 \\
\hline Goals) & $\mathrm{N}$ & 302 & 302 & 301 \\
\hline Academic & Pearson Correlation & $.239^{* *}$ & $.244^{* *}$ & 1 \\
\hline Retention & Sig. (2-tailed) & .000 & .000 & \\
\hline & $\mathrm{N}$ & 301 & 301 & 301 \\
\hline
\end{tabular}

The results in Table 8 shows that there is a weak, significant positive relationship between perceived 
organisational support (employees' welfare) and academic staff retention $(r=0.239, \quad \mathrm{p}=0.000)$. This suggests that retention was high among academics who were satisfied with the support they received from their universities in their welfare matters and vice versa. Further, the results show that there is a weak, significant positive relationship between perceived organisational support (employee's opinions and goals) and academic staff retention $(r=.244, \mathrm{p}=0.000)$. This suggests that retention was high among academics who were satisfied with perceived organisational support (employee's opinions and goals) in their universities or vice versa.

iii. Results of Multiple regression analysis

$\mathrm{H}_{03}$ : The combined effect of employee biographical characteristics and Perceived Organisational Support do not have a significant effect on retention among academic staff in Universities in Kenya

Hypothesis Three was tested using multiple regression analysis. Multiple regression analysis was carried out to determine the joint effect of employee biographical characteristics (namely, gender, age, tenure as an academic, tenure in the university, level of education and job position) and perceived organizational support on academic staff retention.

Model Summary

\begin{tabular}{|c|c|c|c|c|c|c|}
\hline Model & $\mathrm{R}$ & R Square & & Square & \multicolumn{2}{|c|}{ Std. Error of the Estimate } \\
\hline 1 & \multicolumn{2}{|c|}{$.359^{\mathrm{a}}$} & & .102 & & 5.25305 \\
\hline \multicolumn{7}{|c|}{$\begin{array}{l}\text { a. Predictors: (Constant), POS (Employees Opinions and Goals), Tenure in the university, Gender, University } \\
\text { Sector, Level of Education, Age, Position held, POS (Employee Welfare), Tenure as an Academic } \\
\text { ANOVA }^{\text {a }}\end{array}$} \\
\hline \multirow[t]{2}{*}{ Model } & & Sum of Squares & $\mathrm{df}$ & Mean Square & $\mathrm{F}$ & Sig. \\
\hline & Regression & 1190.095 & 9 & 132.233 & 4.792 & $.000^{\mathrm{b}}$ \\
\hline \multirow[t]{2}{*}{1} & Residual & 8030.018 & 291 & 27.595 & & \\
\hline & Total & 9220.113 & 300 & & & \\
\hline
\end{tabular}

a. Dependent Variable: Academic Staff Retention

b. Predictors: (Constant), POS (Employees Opinions and Goals), Tenure in the university, Gender, University Sector, Level of Education, Age, Position held, POS (Employee Welfare), Tenure as an Academic

Coefficients

\begin{tabular}{|c|c|c|c|c|c|c|}
\hline \multirow{2}{*}{\multicolumn{2}{|c|}{ Model }} & \multicolumn{2}{|c|}{$\begin{array}{l}\text { Unstandardized } \\
\text { Coefficients }\end{array}$} & \multirow{2}{*}{$\begin{array}{c}\text { Standardized } \\
\text { Coefficients } \\
\text { Beta } \\
\end{array}$} & \multirow[t]{2}{*}{$\mathbf{t}$} & \multirow[t]{2}{*}{ Sig. } \\
\hline & & $\mathrm{B}$ & Std. Error & & & \\
\hline \multirow[t]{10}{*}{1} & (Constant) & 24.769 & 2.271 & & 10.905 & .000 \\
\hline & Age & -1.089 & .492 & -.164 & -2.214 & .028 \\
\hline & Gender & .160 & .643 & .014 & .249 & .803 \\
\hline & Level of Education & -.089 & .662 & -.009 & -.134 & .894 \\
\hline & Tenure as an Academic & .033 & .342 & .009 & .097 & .923 \\
\hline & Tenure in the university & -.298 & .446 & -.053 & -.667 & .505 \\
\hline & Job Position & -.361 & .364 & -.071 & -.991 & .323 \\
\hline & University Sector & .036 & .633 & .003 & .057 & .955 \\
\hline & POS (Employee Welfare) & .261 & .127 & .147 & 2.063 & .040 \\
\hline & POS (Employees Opinions and Goals) & .287 & .123 & .167 & 2.343 & .020 \\
\hline
\end{tabular}

a. Dependent Variable: Academic Staff Retention

The model summary of the regression analysis in Table 9 shows that employee biographical characteristics (namely, gender, age, tenure as an academic, tenure in the university, level of education and job position) and perceived organizational support explained $12.9 \%$ of the variance in academic staff retention ( $\mathrm{R}$ squared $=.129)$. The standardized beta coefficients have shown that age $(\beta=-.164, p=0.028)$, POS (Employees Welfare) $(\beta=.147$, $p=0.040)$ and POS (Employees Opinions and Goals) $(\beta=.167, p=0.020)$ are significant positive predictors of academic staff retention. The significant negative beta coefficient for age shows that younger academics (Below 30 years) were more likely to remain in their universities than academics aged 30 years and above. Further, the significant positive beta coefficients suggest that POS (Employees Welfare) and POS (Employees Opinions and Goals) positively enhanced retention of academic staff. On the other hand, the standardized beta coefficients show that gender, tenure as an academic, tenure in the university; level of education, job position and university sector did not have any significant effect on academic staff retention $(p>0.05)$. This implies that, with the exception of age, biographical characteristics did not influence academic staff retention.

H04: Perceived Organisational Support does not have a significant effect on retention among academic staff 
in public and private universities in Kenya.

Hypothesis four was tested using multiple regression analysis. Multiple regression analysis was carried out to compare the effect of Perceived Organisational Support on academic staff retention in public and private universities in Kenya.

Table 10: Results of multiple regression analysis establishing the effects of Perceived Organisational Support on academic staff retention in public and private universities

Model Summary

\begin{tabular}{lllll}
\hline University Sector & $\mathrm{R}$ & R Square & Adjusted R Square & Std. Error of the Estimate \\
\hline Public University & $.331^{\mathrm{a}}$ & .110 & .099 & 5.37622 \\
Private University & $.278^{\mathrm{a}}$ & .077 & .062 & 5.20766 \\
\hline
\end{tabular}

a. Predictors: (Constant), POS (Employees Opinions and Goals), POS (Employee Welfare)

\begin{tabular}{|c|c|c|c|c|c|c|}
\hline \multicolumn{7}{|c|}{ ANOVA $^{a}$} \\
\hline \multicolumn{2}{|c|}{ University Sector } & Sum of & & Mean Square & $\mathrm{F}$ & Sig. \\
\hline Public & Regression & 612.301 & 2 & 306.151 & 10.592 & $.000^{\mathrm{b}}$ \\
\hline University & Residual & 4971.448 & 172 & 28.904 & & \\
\hline & Total & 5583.749 & 174 & & & \\
\hline Private & Regression & 279.077 & 2 & 139.539 & 5.145 & $.007^{b}$ \\
\hline University & Residual & 3335.725 & 123 & 27.120 & & \\
\hline & Total & 3614.802 & 125 & & & \\
\hline
\end{tabular}

a. Dependent Variable: Academic Staff Retention

b. Predictors: (Constant), Perceived Organisational Support (Employees Opinions and Goals), Perceived Organisational Support (Employee Welfare)

\begin{tabular}{|c|c|c|c|c|c|c|}
\hline \multicolumn{7}{|c|}{ Coefficients $^{\mathrm{a}}$} \\
\hline & & \multicolumn{2}{|c|}{$\begin{array}{l}\text { Unstandardized } \\
\text { Coefficients }\end{array}$} & \multirow{2}{*}{$\begin{array}{c}\text { Standardized } \\
\text { Coefficients } \\
\text { Beta }\end{array}$} & \multirow[b]{2}{*}{$\mathrm{t}$} & \multirow[b]{2}{*}{ Sig. } \\
\hline \multicolumn{2}{|c|}{ University Sector } & $\mathrm{B}$ & Std. Error & & & \\
\hline Public & (Constant) & 19.380 & 1.407 & & 13.776 & .000 \\
\hline \multirow[t]{2}{*}{ University } & POS (Employee Welfare) & .503 & .159 & .271 & 3.162 & .002 \\
\hline & $\begin{array}{l}\text { POS (Employees Opinions } \\
\text { and Goals) }\end{array}$ & .150 & .139 & .093 & 1.080 & .282 \\
\hline Private & (Constant) & 21.579 & 1.684 & & 12.815 & .000 \\
\hline \multirow[t]{2}{*}{ University } & POS (Employee Welfare) & -.345 & .240 & -.207 & -1.438 & .153 \\
\hline & $\begin{array}{l}\text { POS (Employees Opinions } \\
\text { and Goals) }\end{array}$ & .785 & .273 & .414 & 2.874 & .005 \\
\hline
\end{tabular}

a. Dependent Variable: Academic Staff Retention

The model summary of the regression analysis in Table 10 shows that Perceived Organisational Support explained $11 \%$ of the variance in academic staff retention $(\mathrm{R}$ squared $=.110$ ) in public universities and $7.7 \%$ of the variance in academic staff retention $(\mathrm{R}$ squared $=.077)$ in private universities. Therefore, $89 \%$ and $92.7 \%$ of the variance in academic staff retention in public and private universities respectively was explained by other factors not in the study. The standardized beta coefficients show that POS (employees welfare) was a significant predictor of retention in public universities $(\beta=.271, \mathrm{p}=.002)$ while POS (employees opinions and goals) was insignificant predictor of retention among academic staff $(\mathrm{p}>0.05)$. This shows that retention in public universities improved when management supported academic staff in welfare-related matters. On the other hand, POS (employees opinions and goals) was a significant positive predictor of academic staff retention in private universities $(\beta=.414, p=.005)$ while POS (employees' welfare) was an insignificant predictor of academic staff retention $(\mathrm{p}>0.05)$. This implies that POS employee's opinions and goals in public universities and POSemployees' welfare in private universities did not influence academic staff retention.

\section{Discussions}

The main objective of the study was to determine the effect of employee biographical characteristics and perceived organisational support on academic staff retention in universities in Kenya. Studies have found that biographical characteristics are important in determining employee retention (Agyeman \& Ponniah, 2014; Choong et al., 2013; Segbenya, 2014).

Gender

The results show that there were no statistically significant differences in the mean scores of perceived organisational support and academic staff retention among male and female respondents. This suggests that gender of academic staff did not influence satisfaction or dissatisfaction with perceived organizational support and 
decision to remain in the university. This is consistent with study which found that gender did not have significant influence on voluntary turnover (Murupus \& Kipkebut, 2015; Hayes, 2015; Kamau, 2018). Similarly, Kiragu, Kipkebut \& Kipchumba (2020) found that gender had no influence on decision to quit or stay. Contrary to this finding, Lyness \& Judiesch (2001) found that female managers' voluntary turnover rates were slightly lower than those of their male counterparts. Similarly, Jadoo et al. (2015) found that male employees were more likely to turnover than female employees.

Age

The results show that there were no statistically significant differences in the mean scores of POS (employees' welfare) and POS (employee's opinions and goals) among academic staff in different age groups. This means that age did not influence satisfaction or dissatisfaction with perceived organisational support. On the other hand, the analysis found that retention was higher among academics aged below 30 years than academics aged 40 years and above. Consistent with this study, Kiragu et al. (2020) found that retention was higher among younger academics than older academics. On the other hand, the finding is contrary to studies that have found that older employees were less likely to turnover as compared to younger workers (Murupus \& Kipkebut, 2015; Gibson \& Sodeman, 2014; Okun et al., 2013; Monks, 2012; Choong et al., 2013; Kipkebut, 2013).

\section{Tenure in the university}

The results show that there were no statistically significant differences in the mean scores of POS (employees' welfare) and POS (employee's opinions and goals) among academic staff based on tenure in the university. This means that years worked in the current university did not influence satisfaction or dissatisfaction with perceived organisational support. On the other hand, the analysis showed that academics who had worked in their current universities for 20 years and above were more likely to quit their jobs unlike academics who had worked in their current universities for less than 10 years. It is likely that academics with high tenure are likely to have adequate experience to hold senior positions in other organisations or maybe older employees who have opted for early retirement. This is contrary to studies which found that the employees with high tenure were less likely to turnover unlike those with shorter tenure (Obwoyere \& Kipkebut, 2016; Couch, 2011; Almalki et al., 2012; Lambert et al., 2012).

\section{Tenure as an academic}

The results show that there were no statistically significant differences in the mean scores of POS (employees' welfare) and POS (employee's opinions and goals) among academic staff based on tenure as academicians. This means that years worked as academics did not influence satisfaction or dissatisfaction with perceived organisational support. On the other hand, the analysis showed that academics who had worked as academicians for 16 years and above were more likely to quit their jobs unlike those who had worked as academicians for 15 years and below. It is likely that academicians with many years of experience have attained their highest level of career growth in their universities and thus opt to quit their jobs to take up senior management positions in universities, research institutions among others unlike academics with shorter tenure who are still pursuing career growth in their fields. This is contrary to studies which have found that employees who have worked for a long time in their jobs were less likely to have turnover intentions unlike those who have worked for a shorter time (Obwoyere \& Kipkebut, 2016; Couch, 2011; Almalki et al., 2012; Lambert et al., 2012).

\section{Position}

The results show that there was no statistically significant difference in the mean score of POS (employees' welfare) among academic staff based on job position. This means that position held did not influence satisfaction or dissatisfaction with the support they received from their universities in their welfare matters. Contrary to this finding, Teti \& Andriotto (2014) found a direct linear relationship existed between job standing and welfare satisfaction employees received from their organizations. Further, the analysis showed that Assistant Lecturers had lower mean scores for POS (Employees opinions and goals) than Lecturers. This implies that Lecturers had adequate experience to be involved in decision making unlike Assistant Lecturers who were still inexperienced and working on contractual terms. Consistent with this study, Akuoko, Dwumah, \& Ansong (2012) found that management frequently considered employees opinions and knowledge which aided them in decision making from competent and experienced employees to solve problems than from newly recruited staff. Finally, the analysis showed that Assistant Lecturers had significantly higher mean scores for retention than Professors which implies that Professors were more likely to quit their jobs than Assistant Lecturers. A possible explanation is that Assistant Lecturers, who are newly employed and inexperienced, are more likely to stay unlike Professors who are highly experienced and have opportunities for attractive jobs outside their universities. Consistent with this study, Kiragu et al. (2020) found that retention was higher among Assistant Lecturers while Senior lecturers and Professors were more likely to quit their jobs. This is contrary to previous studies which found that employees in higher designation positions were more likely to stay since they earn higher salaries, have better working conditions, better health facilities and other fringe benefits unlike employees in lower positions (Lambert et al., 2012; Kónya et al., 2016; Gurmessa, Ferreira \& Wissink, 2018). 


\section{Level of Education}

The results show that there were no statistically significant differences in the mean scores of POS (employee's opinions and goals) and retention among academic staff based on level of education. This showed that level of education did not influence retention and satisfaction or dissatisfaction with POS (employee's opinions and goals). This is contrary to previous studies which found that turnover intentions were higher among highly educated employees while retention was higher among employees with lower levels of education (Kipkebut, 2010; Murupus \& Kipkebut, 2015; Choong et al., 2013; Mulwa, 2010; Al Mamun \& Hasan, 2017; Mwilu, 2016). On the other hand, the analysis showed that academics with Doctorate degrees were more satisfied with the support they received from their universities on their welfare matters unlike academics with Bachelors degree. Bachelor degree holders, who are Graduate Assistants, occupy lower position in academic ranks and thus low employee welfare benefits such as pay, incentives, medical insurance among others as compared to highly educated academics. Consistent with this study, Jaoko (2014) found that people with higher levels of literacy and higher academic qualifications were significantly more satisfied with the support they received from their organisations on their welfare matters unlike employees with lower academic qualifications.

\section{University Sector}

The results show that there were no statistically significant differences in the mean scores of perceived POS (employees' welfare), POS (employee's opinions and goals) and retention among academic staff based on the university sector i.e. public and private. This implies that satisfaction or dissatisfaction with Perceived Organisational support and decisions to quit or remain in the job was not influenced by the university sector. This finding is contrary to results of Wang, Yang \& Wang (2012) who found that public sector employees in Taiwan had lower turnover intentions compared to their counterparts in the private sector. On the other hand, Kónya et al. (2016) found that employees in private organisations had higher commitment to stay in their organisations unlike employees in public organisations. Further, the analysis showed that POS (employees' welfare) was a significant positive predictor of retention in public universities. Consistent with this study, Agusioma, Nyakwara, \& Mwiti (2019) found that staff welfare was positively and significantly related to employees' retention in Kenya's public sector. Finally, the analysis showed that POS (employees' opinion and goals) was a significant positive predictor of retention in private universities. Consistent with this study, Snipes \& Taylor, 2016 found that appreciation of employees opinions and goals in the private sector was positively and significantly related to retention.

Perceived Organisational Support (Employees welfare): The results show that perceived organisational support (employees' welfare) had weak, significant positive effect on academic staff retention. This suggests that retention was high among academics who were satisfied with support from their universities on their welfare matters or vice versa. This is consistent with previous studies which found that POS (employees' welfare) positively influenced employee retention (Schmitz and Schrader, 2015; Zhong et al., 2016).

Perceived Organisational Support (Employees opinions and goals): The results showed that perceived organisational support (employees' opinions and goals) had significant positive effect on academic staff retention. This suggests that retention was high among academics when management showed consideration over their opinions and goals or vice versa. This is consistent with previous research which found a significant positive relationship between POS (employees' opinions and goals) and academic staff retention (Hashmi \& Jabeen, 2019; Shields, 2017; Nikhil \& Arthi, 2018). On the other hand, the finding is contrary to studies that did not find a relationship between POS (employees' opinions and goals) and retention (Khalid, 2018; Buck, 2012)

\section{Conclusions}

The main objective of this study was to establish the effect of employee biographical characteristics and perceived organizational support on retention among academic staff in Kenyan universities. The analyses showed that the mean scores of POS (employees welfare) and POS (employees opinion and goals) did not differ significantly on the basis of gender, age, tenure in the university, tenure as an academic and university sector. In addition, the study found that the mean scores of POS (employees' opinions and goals) differed significantly on the basis of job position while mean scores of POS (employees' welfare) differed significantly on the basis of level of education. Further, the results showed that the mean scores of retention differed significantly on the basis of age, tenure in the university, tenure as an academic and job position. The results of correlation analysis showed that POS (employees' welfare) and POS (employees' opinion and goals) had significant positive relationships with academic staff retention. Further, the results of multiple regression analysis showed that age, POS (employees' welfare) and POS (employees' opinions and goals) were significant positive predictors of retention. Finally, the results of multiple regression analysis showed that POS (employees welfare) influenced retention in public universities while POS (employees' opinions and goals) influenced retention in private universities.

\section{Recommendations}

The findings of this study have several recommendations for university top managers in order to improve academic staff retention in their universities. The role of perceived organisational support in academic staff retention should 
be enhanced by the leadership in the universities to achieve better performance. The study has established that retention was high among academics who were satisfied with support from their universities on their welfare matters or vice versa. Universities should improve welfare matters such as pay, incentives, medical insurance among others. The study further established that retention was high among academics when management showed consideration over their opinions and goals or vice versa. Universities managers should be willing to listen to the employees concerns, soliciting their opinions and giving credit for implemented suggestions. The significant effect of biographical characteristics on retention showed that the success of the universities in achieving their objectives was dependent on ensuring that academic staff are satisfied and committed thus enhancing retention and productivity. Specifically, top university policy makers should implement various retention strategies targeting academics in the positions of senior lecturer and professors, older academic (40 years and above) and those with longer tenure in academics (16 years and above) and in their universities (20 years and above). These can include creating a pleasant and supportive work environment, recognition, rewards and provision of adequate training opportunities.

\section{Limitations and Future Research Directions}

The study encountered difficulties in questionnaire administration as it targeted all categories of academic staff. The academic staff works on strict schedules and getting time with them to fill the questionnaires was quite difficult. Lastly, the study was conducted using cross-sectional research design, which means that the data was collected at one point in time and thus was unable to determine the long-term effect of perceived organisational support on retention of academic staff. The study proposes future studies to include some other theoretical variables on employee retention across diversified industries and cross-cultural environments. In the relationship between Perceived Organizational Support and Employee Retention, future researchers may also evaluate the the mediating and moderating functions of other variables by using advanced analytical approaches.

\section{References}

Abdulrab, M., Zumrah, A. R., Almaamari, Q., Al-Tahitah, A. N., Isaac, O. \& Ameen, A. (2018). The role of psychological empowerment as a mediating variable between perceived organizational support and organizational citizenship behaviour in Malaysian higher education institutions. International Journal of Management and Human Science, 2 (3), pp. 1- 14

Abraham, J., Renaud, S. \& Saulquin, J. Y. (2016). Relationships between organizational support, organizational commitment and retention: Evidence from high-potential employees. Global Journal of Business Research, $10(1)$, pp. 11-26.

Alfisyahri, K., Etikariena, A. \& Gatari, E. (2017). The relationship between perceived organizational support and employee's turnover intention through supportive co-worker workshop in division B at Company X. In $1^{s t}$ International Conference on Intervention and Applied Psychology (ICIAP 2017). Atlantis Press.

Allen, D., Bryant, P. \& Vardaman, J. (2010). Retaining talent: Replacing misconceptions with evidence-based strategies. The Academy of Management Perspectives, 24 ( 2), pp. 48-64.

Allen, G., Lynn, M. \& Rodger W. (2003) The role of perceived organizational support and supportive human resource practices in the turnover process. Journal of Management, 29 (1), 99-118.

Almalki, M. J., FitzGerald, G. \& Clark, M. (2012). The relationship between quality of work life and turnover intention of primary health care nurses in Saudi Arabia. BMC Health Services Research, 12 (1), pp. 1-11.

Al Mamun, C. A. \& Hasan, M. N. (2017). Factors affecting employee turnover and sound retention strategies in business organization: A conceptual view. Problems and Perspectives in Management, 15 (1), pp. 63-71.

Arasanmi, C. N. \& Krishna, A. (2019). Linking the employee value proposition (EVP) to employee behavioural outcomes. Industrial and Commercial Training.51 (8), pp. 387- 395.

Agyeman, C. \& Ponniah, V. (2014) Employee Demographic Characteristics and Their Effects on Turnover and Retention in MSMEs. International Journal of Recent Advances Organizational Behaviour and Decision Sciences, 1 (1), pp. 12-29.

Armstrong, M. A. (2007). Handbook of Human Resource Management Practice. London: Kogan Page Limited.

Aselage, J., \& Eisenberger, R., (2003). Perceived organizational support and psychological contracts: A theoretical integration. Journal of Organizational Behavior, 24 (5), 491-509.

Aydın, E. \& Kalemci T. I., (2019). Organizational support sources and job performance relations: what about occupational commitment? Anatolia, 30 (3), pp.379-389.

Brinn, T, Jones, M. J \& Pendlebury, M. (2001). The Impact of research assessment exercises on UK accountancy and finance faculty. British Accounting Review, 33(2) pp.333-355.

Bushe, B., Chiwira, O., \& Chawawa, M. (2012). The impact of academic staff recruitment, development and retention policies at $\mathrm{Ba}$ Isago University College on their commitment to the College. Research Journal of Business Management and Accounting, 1(4), pp. 84- 97.

Carleton University (2000). Report of the task force on faculty recruitment and retention at Carleton University. 
Ottawa: Carleton University.

Chaminade, B (2007). A retention checklist: how do you rate? Www.humanresourcesmagazine.co.au. Accessed, May, 2018

Cheng, L., Cui, Y., Chen, Q., Ye, Y., Liu, Y., Zhang, F. \& Hu, X. (2020). Paediatric nurses' general self-efficacy, perceived organizational support and perceived professional benefits from Class A tertiary hospitals in Jilin province of China: the mediating effect of nursing practice environment. BMC Health Services Research, 20 (1), pp.2-9.

Chelangat, E. C. (2019). Antecedents of Perceived Employee Engagement and Turnover Intention in the Banking Sector in Nairobi City County, Kenya (Doctoral dissertation, JKUAT-COHERD).

Choong,.Y, Keh,.C , Tan. \& Tan, C. (2013). Impacts of Demographic Antecedents toward Turnover Intention amongst Academic Staff in Malaysian Private Universities. Australian Journal of Basic and Applied Sciences, 7 (6): pp. 46-54

Couch, K. A. (2011). Tenure, turnover, and earnings profiles in Germany and the United States. Journal of Business \& Economics Research, 1(9), pp. 1-9

Dabos, G. E., \& Rousseau, D. M. (2004). Mutuality and reciprocity in the psychological contracts of employees and employers. Journal of Applied Psychology, 89 (1), pp. 52.

Dawley, D., Houghton, J. D. \& Bucklew, N. S. (2010). Perceived organizational support and turnover intention: The mediating effects of personal sacrifice and job fit. The Journal of Social Psychology, 150 (3), pp. 238257.

Du Plooy, J. \& Roodt, G. (2013) Biographical and demographical variables as moderators in the prediction of turnover intentions, SA Journal of Industrial Psychology, 39 (1) pp.1-12

Edokat, T. (2000). Effect of Brain Drain on Higher Education in Cameroon. Paper presented at the Regional Conference on Brain Drain and Capacity Building in Africa, Addis Ababa, 22- 24 February.

Eisenberger, R., Shoss, M. K., Karagonlar, G., Gonzalez-Morales, M. G., Wickham, R., \& Buffardi, L. C. (2014). The supervisor POS-LMX-subordinate POS chain: Moderation by reciprocation wariness and supervisor's organizational embodiment. Journal of Organizational Behavior, 35: pp. 635-656.

Eisenberger, R., Malone, G. P., \& Presson, W. D. (2016). Optimizing perceived organizational support to enhance employee engagement. Society for Human Resource Management and Society for Industrial and Organizational Psychology, 22(2) pp. 1-22

Effah, P. (2003). In D. Teferra \& P.G. Altbach (Eds.), African Higher Education: An International Reference Handbook. Bloomington, IN: Indiana University Press.

Gibson, L. A., Sodeman, W. A. (2014). Millennials and technology: Addressing the communication gap in education and practice. Education and Development Journal, 32,pp. 63-75

Govindaraju, N. (2018). Demographic Factors Influence on Employee Retention. International Journal of Engineering Studies and Technical Approach, 4(7) pp. 1- 11

Gurmessa, Z. B., Ferreira, I. W., \& Wissink, H. F. (2018). Demographic Factors as a Catalyst for the Retention of Academic Staff: A Case Study of Three Universities in Sub-Saharan Africa. Journal of Economics and Behavioral Studies, 10 (3), pp. 169-186.

Gupta, Y., Kumar, A. \& Seemarani (2015). A Study of Employee Retention Vs Demographic Variables in IT Units of Pune City. International Journal of Engineering and Management Research, 5 (1), pp. 96-103

Giao, H., Vuong, B.,Huan, D., Tushar, H., \& Quan, T. (2020) The Effect of Emotional Intelligence on Turnover Intention and the Moderating Role of Perceived Organizational Support: Evidence from the Banking Industry of Vietnam. Sustainability, 12 (1) pp. 1-25

Hayes, T. M. (2015). Demographic characteristics predicting employee turnover intentions: Doctoral desertion, Walden University.

Hashmi, M. A., \& Jabeen, F. (2019). Impact of leader-member exchange and perceived organisational support on turnover intention: The mediating effects of psychological stress. International Journal of Business and Society, 18 (3), pp. 449-462

Healy, M. C., Lehman, M., \& McDaniel, M. A. (2016). Age and voluntary turnover: A quantitative review. Personnel Psychology, 48, pp. 335-345

Houenou, P. \& Hoenoue-Agbo, Y. (2003). "Cote d'Ivoire." In African Higher Education: an International Reference Handbook, edited by Damtew Teferra and Philip G. Altbach. Bloomington: Indiana University Press

Huang, Q. \& Gamble, J. (2015). Social expectations, gender and job satisfaction: Front-line employees in China's retail sector. Human Resource Management Journal. 25 (10), pp. 1748-8583.

Iddrisu, S., Alhassan, E., \& Kinder, T. (2014). Polytechnic Education in Ghana: Management Delivery and Challenges. The International Journal of Social Sciences and Humanities Invention, 1 (6), pp. 2349-2031.

Jadoo, S.A.A., Aljunid, S.M., Dastan, L., Tawfeeq, R.S., Mustafa, M.A., Ganasegeran, K. \& AlDubai, S.A.R., (2015) Job Satisfaction and Turnover Intention among Iraqi doctors: A descriptive cross-sectional multicenter 
study, Human Resources for Health, 13 (21), pp.1-11.

Jayasundera, A \& Jayakody, S \& Jayawardana, A. (2017). Perceived Organizational Support and Turnover Intention of Generation Y Employees: The Role of Leader-Member Exchange. Sri Lankan Journal of Management. Sri Lankan Journal of management, 21 (2), pp. 1 -36

K’osuri M. A., Eggesa, R. \& Onyango, R. (2020). Perceived organizational support, psychological empowerment and employee engagement in public health facilities in Kenya. A review. The Strategic Journal of Business \& Change Management, 7(2), pp. $70-85$.

Khalid, K., \& Nawab, S. (2018). Employee participation and employee retention in view of compensation. SAGE Open, $8(4)$, pp. 21-58

Kamau, M. M. (2018). Factors affecting employees' voluntary turnover: A case of Deloitte \& Touche Kenya. Doctoral dissertation, Strathmore University, Kenya.

Kipkebut, D. J. (2010). Organisational Commitment in Public and Private Universities in Kenya. The Journal of Management, Computer Science \& Journalism. 5(2) 77-92.

Kiragu, L. N., Kipkebut, D. J. \& Kipchumba, S. (2020). Effect of Employee Demographic Characteristics and Talent Management Practices on Academic Staff Retention: A Case of Academic Staff in Universities in Kenya. International Journal of Business Management and Finance, 3 (2), pp. 306-325

Kónya, V., Matić, D. \& Pavlović, J. (2016). The Influence of Demographics, Job Characteristics and Characteristics of Organizations on Employee Commitment, Acta Polytechnica Hungarica, 13 (3), pp. 119138

Lambert, E. G., Cluse-Tolar, T., Pasupuleti, S., Prior, M. \& Allen, R. I. (2012). A test of a turnover intent model. Administration in Social Work, 36, pp. 67-84.

Lyness, K. S. \& Judiesch, M. K. (2001). Are female managers' quitters? The relationships of gender, promotions, and family leaves of absence to voluntary turnover. Journal of Applied Psychology, 86 (6), pp. $1167-1178$.

Manogharan, M. W., Thivaharan, T., \& Rahman, R. A. (2018). Academic Staff Retention in Private Higher Education Institute--Case Study of Private Colleges in Kuala Lumpur. International Journal of Higher Education, 7 (3), pp. 52-78.

Mensah, J.P., Augustine, A. F. \& Oteng, E. (2017). The Effect of Demographic Variables on Work Attitudes and Intentions to Quit: The Case of the Hotel Industry in Cape Coast and Elmina 5(7), pp. 46-61.

Mbirithi, D. M. (2013). Management Challenges Facing Kenya's Public Universities and Implications for the Quality of Education. Doctoral dissertation, Kenyatta University, Kenya

Miring'u, W. (2016). Perceived Influence of Organisational Support on Organisational Commitment in Githunguri Dairy Co-Operative Society Limited. Doctoral dissertation, University of Nairobi, Kenya.

Monks, J. (2012). Job turnover among university presidents in the United States of America. Journal of Higher Education Policy \& Management, 34, pp. 139-152.

Mubarak, R., Wahab, Z., \& Khan, N. (2012). Faculty Retention in Higher Education Institutions of Pakistan. International Journal of Theories and Research in Education, 7(2), pp. 65-78.

Mugenda, O. M. \& Mugenda, A. G. (2012) Research Methods: Quantitative and Qualitative Approaches. Nairobi, Kenya: ACTS Press.

Mukwhana, E., Oure, S., Kiptoo, S., Kande, A., Njue, R., Too, J., Njeru, M., Walela, P. \& Some, D. K. (2016). State of University in Kenya. Commission for University Education. Discussion paper 04. Nairobi, Kenya

Mulwa, P. M. (2010). Factors that influence staff turnover in World Vision International Somalia. Doctoral dissertation, University of Nairobi, Kenya

Mwilu, J. M. (2016). Factors influencing employee turnover in the hotel industry in Machakos town, Machakos County. Doctoral dissertation, South Eastern Kenya University, Kenya.

Njanjobea, I. L. (2016). An investigation into talent management and employee retention in the higher education sector of South Africa: a case of the Durban University of Technology (Doctoral dissertation-Durban University of Technology).

Nassiuma D. K. (2000). Survey sampling: Theory and methods. Njoro, Kenya: Egerton University Press.

Neves, P. \& Eisenberger, R. (2014). Perceived Organizational Support and Risk Taking. Journal of Managerial Psychology, 29 (2), pp. 187-205.

Ng, T. H., \& Sorensen, K. L., (2008). Toward a Further Understanding of the Relationships between Perceptions of Support and Work Attitudes - A Meta-Analysis. Group and Organization Management, 33(3), 243-268.

Nikhil, S., \& Arthi, J. (2018). Perceived organisational support and work engagement: mediation of psychological capital-a research agenda. Journal of Strategic Human Resource Management (JSHRM), 7(1).pp. 1 - 12

Nurjaman, K., Marta, M. S., Eliyana, A., \& Kurniasari, D. (2019). Proactive work behavior and innovative work behavior: Moderating effect of job characteristics. Humanities \& Social Sciences Reviews, 7 (6), pp. 373-379.

Okun, M., Infurna, F. J. \& Hutchinson I. (2016) Are volunteer satisfaction and enjoyment related to cessation of volunteering by older adults? Journals of Gerontology Series B-Psychological Sciences and Social Sciences, 71(3), pp.439-444. 
Oni, B. (2000). The Demand for University Graduates and Employers' Assessment of Graduate Skills in Nigeria. Mimeo. Ibadan: NISER.

Pack, S. M., Jordan, J. S., Turner, B. A. \& Haines, D. (2007). Perceived organizational support and employee satisfaction and retention. Recreational Sports Journal, 31(2), 95-106.

Radhi, M. M., \& Mark P. Doblas. (2020). Demographic Characteristics as Antecedents for Propensity to Stay among Employees of Rosemarry Contracting Company in the Kingdom of Bahrain. Journal of Business and Economics, 1 (2), 34-43.

Rhoades, L. \& Eisenberger, R. (2002). Perceived Organizational Support: A Review of the Literature. Journal of Applied Psychology, 87 (4), pp. 698- 714

Robinson, D. (2004). The status of higher education teaching personnel in Australia, Canada, New Zealand, the United Kingdom, and the United States. Report produced for Education International. Ottawa: Canadian Association of University Teachers.

Samad, S. (2016). The contribution of demographic variables: job characteristics and job satisfaction on turnover intentions. Journal of International Management Studies, 1(1).

Sanderson, A., Phua, V. \& Herda, D. (2000). The American faculty poll. TIAA-CREF, New York: National Opinion Research Center, Illinois: Chicago.

Satardien, M. (2014). Perceived organisational support, organisational commitment and turnover intentions amongst employees in a selected company in the aviation industry. Doctoral dissertation, University of the Western Cape, South Africa

Schuler, R. S., Jackson, S. E., \& Tarique, I. (2011). Global talent management and global talent challenges: Strategic opportunities for IHRM. Journal of World Business, 46 (4), pp. 506- 516.

Segbenya, M. (2014). The Effects of Demographic Variables on Employees ${ }^{\text {ee }}$ Decisions to Stay or Quit in Ghana Commercial Bank, Kumasi. European Journal of Business and Management, 6 (12), 145-153.

Selesho, M. J. \& Naile, I. (2014). Academic Staff Retention as a Human Resource Factor: University Perspective. International Business and Economics Research Journal, 13 (2) 1295- 304.

Shah, M., \& Asad, M. (2018). Effect of motivation on employee retention: Mediating role of perceived organizational support. European Online Journal of Natural and Social Sciences, 7 (2), pp-511.

Shields, R. (2017). The Role of Perceived Organisational Support and the impact of its constructs on Teacher Retention. Doctoral dissertation, University of Pretoria, South Africa.

Sule, O. E. \& Omoankhalen, J. A. (2019). Employee Demographic Factors and Academic Staff Labour Turnover in Private Higher Institutions in Ogun State. Cross Current International Journal of Economics, Management and Media Studies, 1 (1), pp. 30-38.

Tettey, J. W. (2006). Developing and Retaining the Next Generation of Academics in Africa: An Analysis of Issues and Challenges. AAU Newsletter, 15 (1), pp. 1-9.

The Laurier Institution (2000). Renewal and Retention: Attracting and Keeping Faculty and Senior Administrators at British Columbia Universities. Vancouver, The Laurier Institution.

Too, E. K., Chepchieng, M. C., \& Ochola, J. (2015). Effect of academic staff retention on quality education in private universities in Kenya. Journal of Education in the $21^{\text {st }}$ Century. 64 (1), pp. 86-94.

Wang, Y. D., Yang, C., \& Wang, K. Y. (2012). Comparing public and private employees' job satisfaction and turnover. Public Personnel Management, 41(3), pp. 557-573.

Wann-Yih, W. \& Hatik, S. (2011). The Impacts of Perceived Organizational Support, Job Satisfaction, and Organizational Commitment on Job Performance in Hotel Industry. The 11th International DSI and the 16th APDSI Joint Meeting, Taipei, Taiwan, July 12-16.

Waswa, F. \& Katana, G. (2008). Academic Staff Perspectives on Operating Beyond Industrial Actions for Sustainable Quality Assurance in Public Universities in Kenya. International Journal of Environment, Workplace and Employment, 4 (1), pp. 45-58.

Wong, Y. W., \& Wong, Y. T. (2017). The effects of perceived organisational support and affective commitment on turnover intention. Journal of Chinese Human Resource Management. 8(1), 2-21

Yamane, T. (1967). Statistics: An Introductory Analysis. (2nd Ed.) New York: Harper and Row. 